\title{
EFFECT OF SHADING ON THE WATER USE EFFICIENCY OF WINTER WHEAT (TRITICUM AESTIVUM L.) IN SEMI-ARID AND SEMI-HUMID REGIONS OF CHINA
}

\author{
SHEN, Y. B. - ZHANG, J. F. - LI, T. \\ State Key Laboratory of Eco-hydraulics in Northwest Arid Region, \\ $X i$ 'an University of Technology, Xi'an 710048, China \\ (phone: +86-029-8231-2768) \\ *Corresponding author \\ e-mail:litao@xaut.edu.cn \\ (Received $7^{\text {th }}$ Jul 2020; accepted $17^{\text {th }}$ Sep 2020)
}

\begin{abstract}
Solar radiation has a substantial influence on winter wheat (Triticum aestivum L.) growth and water consumption. To elucidate the effect of solar radiation on the yield and water consumption of winter wheat, two-season pot experiments were conducted at Xi'an University of Technology in China from 2015 to 2017. Four shading treatments and a non-shaded control (CK) treatment were applied using black shading net, including $80 \%$ (L80), $60 \%$ (L60), 40\% (L40), and 20\% (L20) of the CK. With the increase in the shading degree, the time of winter wheat growing stage was prolonged, but the dry matter accumulation and water consumption decreased. The maximum of the water consumption and water consumption intensity for the winter wheat occurred at the filling stage, and the water-saving rate was higher than the shading rate from heading to the mature period under the L80 treatment. The water-use efficiency (WUE) under the L80 treatment and CK did not differ significantly. The harvest index for the L80 treatment was higher than that of the CK. To obtain high WUE, wheat must not receive less than $80 \%$ of solar radiation.
\end{abstract}

Keywords: solar radiation, pot experiment, shading net, evapotranspiration, harvest index

\section{Introduction}

Solar radiation is the energy source of all things and the most important factor that affects photosynthesis (Kalyanasundaram and Graetzel, 2010). Plant leaf photosynthesis and transpiration are both driven by solar energy. When the radiation reaches the saturation point of the crop, the photosynthetic rate no longer increases with higher radiation, but the transpiration rate does. A total of $98-99 \%$ of the water absorbed by the roots is dispersed into the air in the form of water vapor, and only approximately $1 \%$ of the water is absorbed for the growth of the plants. Crop water use efficiency is essentially the ratio of the photosynthates to water consumption. Based on the influence of the light intensity on photosynthesis and transpiration, the WUE must change when the solar radiation changes.

During the day, the radiation periodicity changes, and the daily evapotranspiration (ET) of the crops also shows obvious diurnal regularity. From dawn to sunrise, the ET is at the lowest level during the day. After sunrise, with the increase in light intensity, the physiological activities of the crops become more active, and the ET gradually increases before gradually decreasing with the decrease in the radiation intensity ( $\mathrm{Yu}$ and Wang, 2010). These laws all indicate that solar radiation intensity has an effect on the ET, and a moderate reduction of the radiation intensity is accompanied by a decrease in water consumption. Most of the arid and semiarid areas in China are in the northwest with abundant radiation resources and large amounts of daily radiation but a lack of water 
resources. This region has substantial potential to benefit from the control of solar radiation.

There are two primary aspects of the current research on solar radiation control. One is the effect of shading on crop yield and quality. This research is based on the fact that environmental problems, such as air pollution and an increase in aerosol particles, resulting in a significant reduction in solar radiation reaching the Earth's surface ( $\mathrm{Li}$ et al., 2010; Mu et al., 2010; Haywood et al., 2011), or crop interplanting, resulting in a reduction in the light intensity received by the crops underneath (Gommers et al., 2013; Xie et al., 2017). Focusing on the Yangtze River Basin and the Huang-Huai-Hai region, many studies have been conducted on the effects of the reduction in radiation on crop yield and quality (Mo et al., 2015; Ili et al., 2017). These studies mostly utilize white or black shading nets with different layers and needles to obtain different shading degrees (SDs). Where the SD gradient is lower, the SD range of the light is relatively centralized, and the SD is generally larger. Thus, the time for shading is shorter and more concentrated on certain growing stages of the crops. Most of the measurements involve the reduction in yield and quality. Recent studies have also shown that when the intensity of the natural light is $88 \%$ lower, there is an increase in yield due to the prolonged leaf growth (Mu et al., 2010; Xu et al., 2016). These studies focused on the effects of light intensity on crop growth indicators and yield but did not consider crop water consumption. Besides, changes in the growth of the crop indicate their impact on water consumption.

The effect of shading on economic crops is primarily concentrated in orchards. The results show that the shading nets can reduce solar radiation, prevent fruit burns, and reduce damage from hail (Bogo et al., 2012) and birds (Ashraf and Harris, 2013). A reduction in solar radiation also improves orchard microclimate. At high radiation and temperature, shading can reduce the temperature, increase the relative humidity of the air and reduce the wind speed (Lopez et al., 2018; Mupambi et al., 2018). Thus, this shading reduces water consumption (McCaskill et al., 2016). Shading increased the photosynthesis in fruit trees under a water deficit but also decreased the total absorption of light (Girona et al., 2012). The yield and light absorption increased approximately linearly. In the case of excess radiation, the protection and recovery of photosynthesis will consume photosynthates; thus, increasing the accumulation of dry matter. These studies indicated that the protection of fruit trees by a shading network will reduce water consumption and increase the yield of the fruit. However, for field crops, the use of shading to change their water consumption, as measured by the daily water consumption, water consumption in different growing stages, and the trend of WUE, merits further study.

With the increases in aerosols, air pollutants, and population density, dimming, or shading have become major challenges to crop production in many areas of the world (Mu et al., 2010). Experiments with relative heavy shading treatments were applied, the grain yield decreased. Whether evapotranspiration decrease at the same time needs further research. In this study, the winter wheat (Triticum aestivum L.) planting area accounts for nearly $22 \%$ of the total sown area of grain crops (NBS, 2014) was selected as the experimental object. As a C3 specie, wheat is more susceptible to photoinhibition under high solar radiation than $\mathrm{C} 4$ plants. The photosynthetic rate is relatively low, and the $\mathrm{CO}_{2}$ concentrating mechanism operates at higher leaf conductance (Sonoike, 2011; Tikkanen et al., 2014; Guidi et al., 2019). Radiation control experiments were conducted to clarify the effects of the long-term control of radiation on wheat 
photosynthetic growth, the trend of wheat evapotranspiration under different shading degrees, the key period of water consumption, and the influence of the law of shading on the wheat yield and water use efficiency.

\section{Materials and methods}

\section{Experimental site}

Two-season pot experiments were conducted from October 2015 to June 2017 at the experimental site at the Xi'an University of Technology, Xi'an, Shaanxi Province, China $\left(108^{\circ} 93^{\prime} \mathrm{E}, 34^{\circ} 23^{\prime} \mathrm{N}, 416 \mathrm{~m} \mathrm{H}\right)$. The soil type was a loam containing $10.0 \mathrm{~g} \mathrm{~kg}^{-1}$ organic matter, $1.30 \mathrm{~g} \mathrm{~kg}^{-1}$ total nitrogen, $22.3 \mathrm{mg} \mathrm{kg}^{-1}$ available phosphate, and $110.51 \mathrm{mg} \mathrm{kg}^{-1}$ available potassium. The soil bulk density was $1.41 \mathrm{~g} \mathrm{~cm}^{-3}$ with a $\mathrm{pH}$ of 8.03. The climate data during the experimental period were shown in Figure 1.

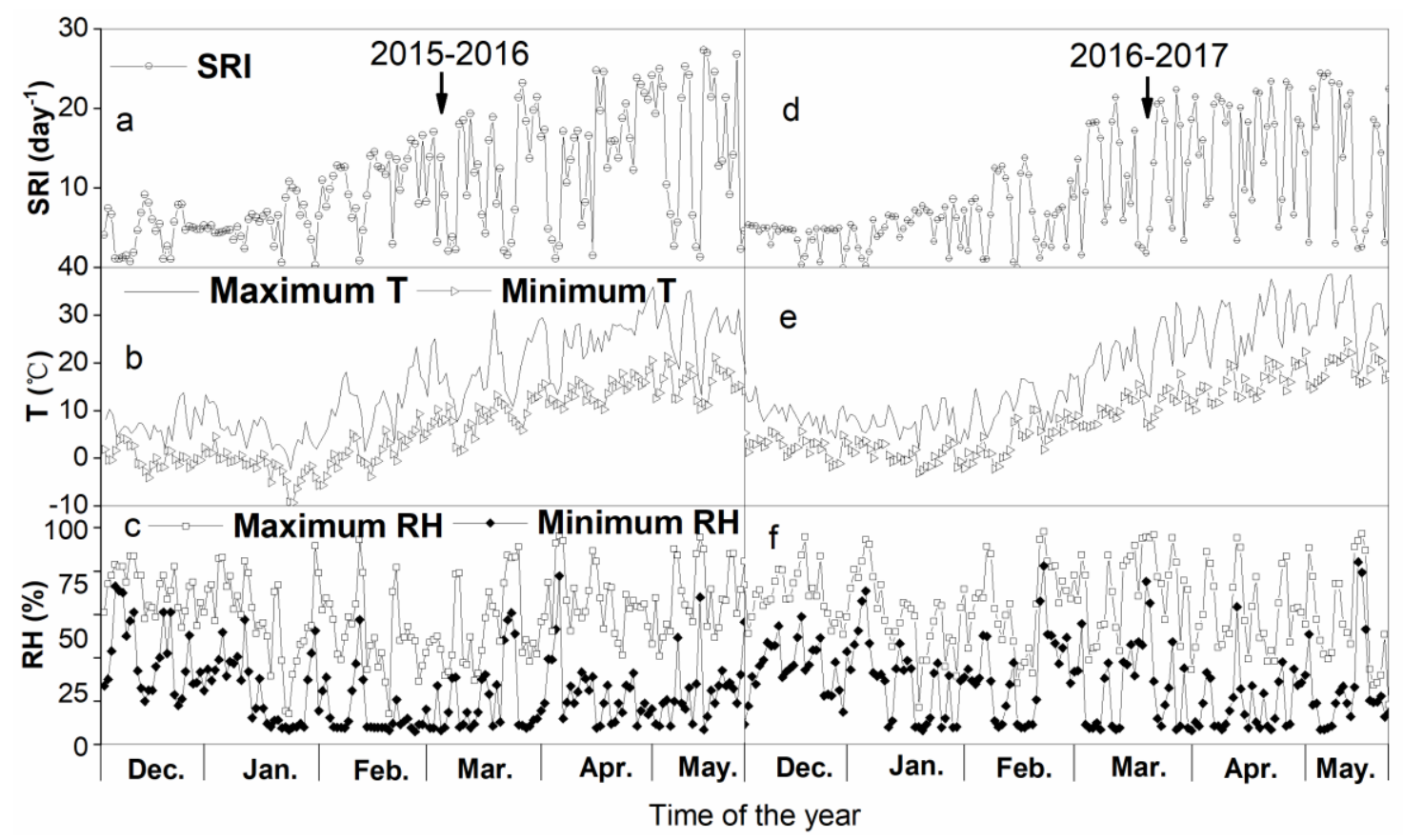

Figure 1. Solar radiation intensity (SRI, $a, d)$, temperature $(T, b, e)$, relative humidity $(R H, c, f)$ in the atmosphere during the shading period in 2015-2016 and 2016-2017

\section{Experimental design and field management}

One cultivar of winter wheat (Triticum aestivum L.) currently used in local production, 'Xinong 979', was chosen for the pot experiments. The top of the wheat canopy was shaded using black polyethylene screens with different needle numbers and layers from the wintering (December 20th 2015, December 18th 2016) to the maturity periods (May 28th 2015, May 24th 2016). The shading net was $20 \mathrm{~cm}$ above the wheat canopy. Five treatments were set up: (1) full radiation, CK; (2) $80 \%$ of full radiation with 1 layer 2 needles black polyethylene screen, L80; (3) $60 \%$ of full radiation with 1 layer 3 needles black polyethylene screen, L60; (4) 40\% of full radiation with 1 layer 2 needles and 1 layer 3 needles black polyethylene screen, L40; and (5) 20\% of full radiation with 1 layer 6 needles black polyethylene screen, L20. Five treatments were 
established with four replications, 20 treatments in total. The shading experimental culture layout was shown in Figure 2.
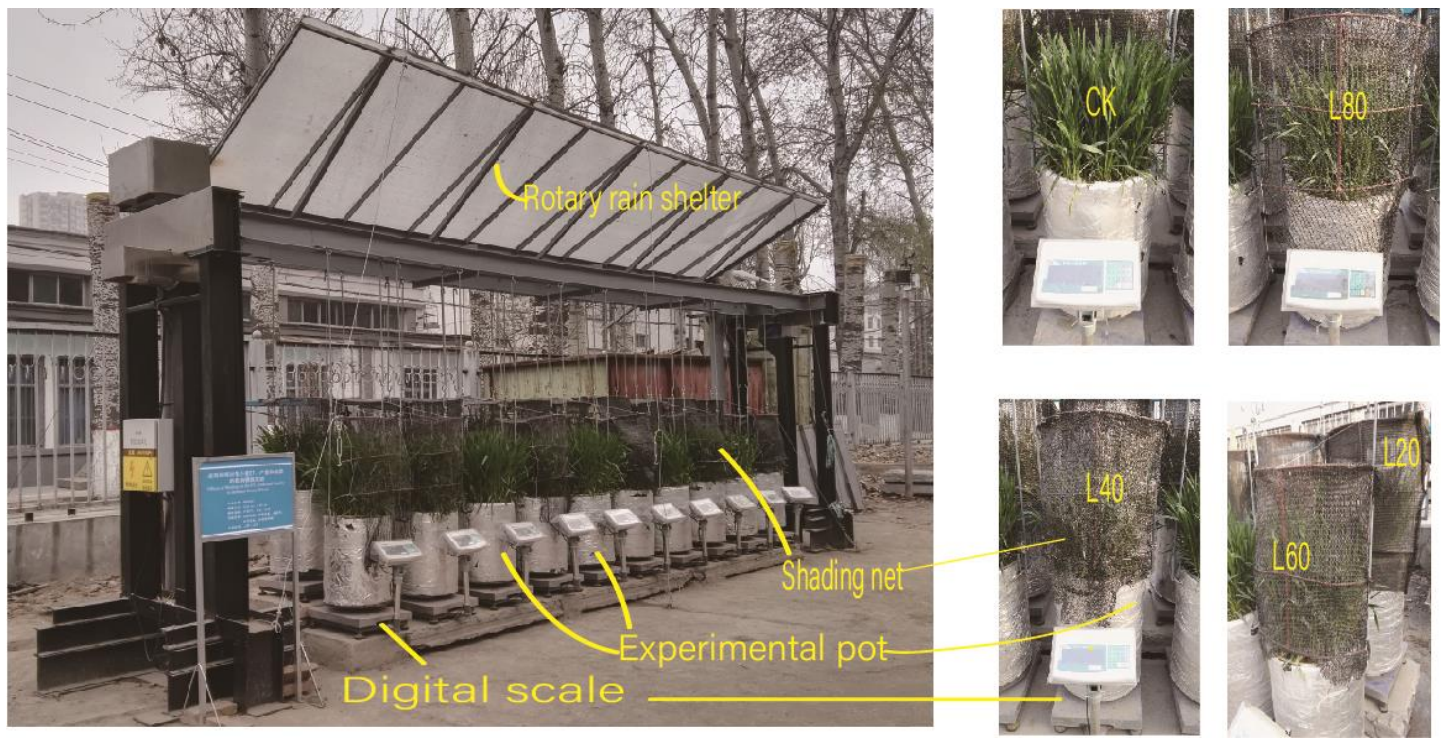

Figure 2. Image of shading experimental culture. CK refers to the no shading treatment (control), L80, L60, L40, and L20, refer to 80\%, 60\%, 40\%, and $20 \%$ of the incident solar radiation, respectively

The size of each pot was $0.4 \mathrm{~m}$ in diameter and $0.6 \mathrm{~m}$ in height. The pots were placed under a rotary rain shelter, which could change the rotation angle to keep radiation indirectly, erected in the experimental site. Each pot was uniformly packed with $90 \mathrm{~kg}$ soil at a bulk density of $1.41 \mathrm{~g} \mathrm{~cm}^{-3}$. Fifty wheat seeds were broadcast sown in each pot on October 18, 2015, and October 16, 2016, and four weeks after sowing, thinning was done to obtain the desired density of 40 seedlings per pot. The pot experiments were well irrigated with the soil water content (SWC) ranging from $65 \%$ to $95 \%$ of field capacity (FC). When the SWC of some treatments was near $65 \%$ of $\mathrm{FC}$, all the treatments were irrigated to $95 \%$ of $\mathrm{FC}$. The SWC was maintained by weighing the pot and its contents. $\mathrm{N}, \mathrm{P}_{2} \mathrm{O}_{5}$ and $\mathrm{K}_{2} \mathrm{O}$ were applied as base fertilizers at 220,150 and $150 \mathrm{~kg} \mathrm{ha}^{-1}$, respectively. A total of $75 \mathrm{~kg} \mathrm{ha}^{-1} \mathrm{~N}$ was applied as a top dressing in the wintering period. Fungicides were sprayed to against powdery mildew.

\section{Measurements and methods of the microclimate in the pot experiments}

\section{Microclimate in the pot experiments}

The temperature and relative humidity $(\mathrm{RH})$ of the canopy under the shading screens were measured using a thermohygrometer (WS-1, Tianjin Fengyang Co. Ltd., China). Photosynthetically active radiation (PAR) was measured using a Li-6400 system (Licor, USA). All the data were monitored every $60 \mathrm{~min}$ from 8:00 to 20:00 for 30 days after anthesis. The data measured were shown in Table 1. The daily meteorological data of the atmosphere, including temperature, $\mathrm{RH}$ and total radiation, were recorded every 5 min using a portable automatic weather station (Watchdog 2900ET, Spectrum Technologies Inc., USA). 
Table 1. Changes in the temperature, relative humidity and photosynthetically active radiation in the canopy under the shading conditions

\begin{tabular}{c|c|c|c|c|c|c|c|c|c|c|c|c|c|c}
\hline \multicolumn{2}{c|}{ Treatment } & $\mathbf{8 : 0 0}$ & $\mathbf{9 : 0 0}$ & $\mathbf{1 0 : 0 0}$ & $\mathbf{1 1 : 0 0}$ & $\mathbf{1 2 : 0 0}$ & $\mathbf{1 3 : 0 0}$ & $\mathbf{1 4 : 0 0}$ & $\mathbf{1 5 : 0 0}$ & $\mathbf{1 6 : 0 0}$ & $\mathbf{1 7 : 0 0}$ & $\mathbf{1 8 : 0 0}$ & $\mathbf{1 9 : 0 0}$ & $\mathbf{2 0 : 0 0}$ \\
\hline \multirow{5}{*}{$\begin{array}{c}\text { Temperature } \\
\left({ }^{\circ} \mathrm{C}\right)\end{array}$} & CK & 14.9 & 16.2 & 18.4 & 22.7 & 22.1 & 24.6 & 26.1 & 25.4 & 24.8 & 22.5 & 21.5 & 19.5 & 18.5 \\
& L80 & 13.9 & 14.6 & 15.5 & 19.8 & 21.5 & 22.4 & 24.0 & 25.3 & 25 & 23.2 & 20.7 & 19.4 & 18.5 \\
& L60 & 14.2 & 14.4 & 15.4 & 18.7 & 20.6 & 21.7 & 23.4 & 23.5 & 24.3 & 22.5 & 20.6 & 19.4 & 18.3 \\
& L40 & 14.1 & 14.4 & 15.5 & 18.5 & 20.7 & 21.5 & 23.4 & 24.1 & 24.2 & 22.1 & 20.4 & 19.6 & 18.5 \\
& L20 & 14.3 & 14.5 & 15.3 & 18.2 & 20.6 & 21.6 & 23.3 & 24.2 & 24.1 & 21.5 & 20.3 & 19.4 & 18.4 \\
\hline \multirow{6}{*}{$\begin{array}{c}\text { Relative humidity } \\
(\%)\end{array}$} & CK & 60.8 & 55.4 & 53.4 & 46.5 & 46.3 & 42.4 & 37.8 & 35.5 & 33.4 & 34.7 & 38.3 & 40.1 & 44.9 \\
& L80 & 62.1 & 54.7 & 53.6 & 49.4 & 46.3 & 41.5 & 39.5 & 36.4 & 33.4 & 36.6 & 40.5 & 41 & 50.8 \\
& L60 & 61.2 & 52.6 & 54.3 & 51.5 & 47.7 & 43.4 & 39.7 & 37.8 & 35.5 & 36.7 & 41.8 & 41.4 & 50.4 \\
& L40 & 60.8 & 55.3 & 57.6 & 54.3 & 48.5 & 44.5 & 39.1 & 37.5 & 36.8 & 39.5 & 40.7 & 41.8 & 50.2 \\
& L20 & 61.4 & 51.2 & 53.4 & 49.7 & 48.8 & 45.6 & 40 & 38.6 & 36.7 & 39.4 & 41.5 & 41.9 & 51 \\
\hline \multirow{4}{*}{$\begin{array}{c}\text { Photosynthetically } \\
\text { active radiation } \\
\left(\mu \text { mol } \mathrm{m}^{2} \mathrm{~s}^{-1} \text { ) }\right.\end{array}$} & CK & 425 & 701 & 818 & 1017 & 1121 & 1205 & 1189 & 1128 & 903 & 417 & 65 & 7 & 0 \\
& L20 & 325 & 556 & 649 & 813 & 902 & 961 & 945 & 894 & 700 & 315 & 49 & 5 & 0 \\
& L40 & 246 & 400 & 478 & 604 & 678 & 718 & 699 & 675 & 530 & 240 & 35 & 4 & 0 \\
& L60 & 164 & 279 & 321 & 400 & 450 & 474 & 460 & 435 & 350 & 150 & 21 & 2 & 0 \\
& L80 & 71 & 126 & 152 & 200 & 226 & 246 & 258 & 238 & 145 & 60 & 8 & 2 & 0 \\
\hline
\end{tabular}

CK refers to the 'no shading' treatment (control), L80, L60, L40, and L20, refer to 80\%, 60\%, 40\%, and $20 \%$ of the incident solar radiation, respectively. The data were the average values on March 18th in 2016

\section{Winter wheat growing stages}

Winter wheat growing stages were defined base on the Irrigation Experiment Standard (SL13-2015) of China. Winter wheat growth stage was defined as ten percent of pot winter wheat got in one growth stage.

\section{Grain yield components}

At the maturity stage of winter wheat, the spike numbers and grain yield (GY) were measured of each pot. Also, 20 representative plants were selected consecutively in each pot, and the kernel numbers per spike and 1000-grain weight were examined in the experiment. All plant parts (leaves, spikes, and stems) were oven dried at $60{ }^{\circ} \mathrm{Cfor} 72 \mathrm{~h}$ to calculate dry matter accumulation (DMA). Harvest index (HI) was calculated as the ratio of GY to DMA. Measurement was performed according to the Irrigation Experiment Standard (SL13-2015) of China.

\section{Evapotranspiration and water use efficiency}

The experimental pots were weighed every day at 8:00 am using digital scales (TCSCC, Fuzhou Kedi Electronic Technology Co., Ltd., China) to calculate the water consumption. The water consumption over time was calculated using a water balance equation that incorporates the difference in the weight of the pots with their plants and soil and the mass of water added to them. The ET was calculated as

$$
E T=\frac{\Delta W+W_{\mathrm{a}}}{S}
$$

where $\Delta \mathrm{W}$ is the pot weight difference, $\mathrm{kg} ; \mathrm{W}_{\mathrm{a}}$ is the mass of added water, $\mathrm{kg}$; and $\mathrm{S}$ is the area of the pot, $\mathrm{m}^{2}$. The daily mean evapotranspiration of each growing stage $\left(\mathrm{ET}_{\mathrm{dm}}\right)$ 
was calculated as divide the evapotranspiration in each growing stage $\left(\mathrm{ET}_{\mathrm{gs}}\right)$ by days of each growing stage. The experimental pots were weighed every $2 \mathrm{~h}$ on typical sunny days February 25th, March 22nd, April 7th, April 28th, May 15th 2016 for each growing stage to obtain the typical day ET. The wheat WUE was determined as follows:

$$
W U E=\frac{G Y}{W E T}
$$

where GY is grain yield of winter wheat, $\mathrm{kg} \mathrm{ha}^{-1}$; WET is the whole growth period evapotranspiration of each pot, mm. WET was considered the equivalent of the total amount of irrigation plus the soil water in pots before sowing minus the residual after final harvest.

\section{Statistical analysis}

All the data were subjected to a one-way analysis of variance, and Duncan's Range Test was used to determine the significance of the differences between the treatments using SPSS statistical software (SPSS 20.0) (SPSS, Inc., USA).

\section{Results}

\section{The microclimate of the pot experiment}

Figure 1 shows the changes in solar radiation intensity (Fig. $1 a$ and $d$ ), temperature (Fig. $1 b$ and $e$ ), and relative humidity (Fig. $1 c$ and $f$ ) in the atmosphere during the shading period. The solar radiation intensity (SRI, Fig. $1 a$ and $d$ ) and temperature (Fig. $1 b$ and $e$ ) increased roughly from January to May. The accumulated SRI from January to March in 2016 was higher than that in 2017, but that was lower from April to May. The total SRI with a value of $91.32 \mathrm{MJ} \mathrm{m}^{-2}$ in 2016 was higher than that in 2017 during the shading period. SRI under shading nets was shown as PAR, as shown in Table 1. In the period of high radiation intensity 10:00-16:00 light control met the design requirements, the rest of the day due to the solar radiation angle was too small, shading rate was higher.

Table 1 displays the change in temperature and $\mathrm{RH}$ in the canopy under the shadings condition of March 18, 2016. The canopy temperature decreased as the shading degree increased, compared with the $\mathrm{CK}$. The temperature at $14: 00$ decreased by $2{ }^{\circ} \mathrm{C}, 3{ }^{\circ} \mathrm{C}$, $3{ }^{\circ} \mathrm{C}$, and $3{ }^{\circ} \mathrm{C}$ under the L80, L60, L40 and L20 treatment, respectively. The RH in the canopy increased with the reduction in solar radiation under the shading treatments. Compared with the CK, the RH increased by $1.0 \%, 3.0 \% 4.0 \%$ and $5.0 \%$ at $14: 00 \mathrm{pm}$ for the L80, L60, L40 and L20 treatments, respectively.

\section{Crop growing duration}

The days of the whole growth period increased from 215 to 225 with an increase in the intensity of shading (Table 2).

Except for the booting stage, shading had a significant effect on crop growing duration, while a significant difference $(\mathrm{p}<0.05)$ was observed from sowing to the tillering stage to flowering. However, there was no significant interaction $(p>0.05)$ of shading and year during growth stages. Compared with the $\mathrm{CK}$, the days of the jointing stage were prolonged by $0,2,4$, and 5 days in 2016 and 1, 2, 3, and 4 days in 2017 for 
the L80, L60, L40, and L20 treatments, respectively. The wintering period in 2016 was longer than that in 2017, while the joining stage was shorter than in 2017.

Table 2. Days (day) of different wheat-growing stages under different treatments

\begin{tabular}{|c|c|c|c|c|c|c|c|c|c|c|}
\hline Years & Treatment & $\begin{array}{c}\begin{array}{c}\text { Sowing to } \\
\text { tillering } \\
\text { stage }\end{array} \\
\end{array}$ & $\begin{array}{c}\text { Wintering } \\
\text { period }\end{array}$ & $\begin{array}{l}\text { Green } \\
\text { stage }\end{array}$ & $\begin{array}{c}\text { Joining } \\
\text { stage }\end{array}$ & $\begin{array}{l}\text { Booting } \\
\text { stage }\end{array}$ & $\begin{array}{l}\text { Heading to } \\
\text { flowering }\end{array}$ & $\begin{array}{c}\text { Filling } \\
\text { stage }\end{array}$ & $\begin{array}{l}\text { Mature } \\
\text { period }\end{array}$ & $\begin{array}{l}\text { Whole } \\
\text { growth } \\
\text { period }\end{array}$ \\
\hline \multirow{5}{*}{$\begin{array}{l}2015- \\
2016\end{array}$} & CK & $63 \mathrm{a} \uparrow$ & $50 \mathrm{~b}$ & $12 \mathrm{~b}$ & $28 \mathrm{~b}$ & $11 \mathrm{a}$ & $22 \mathrm{a}$ & $16 \mathrm{a}$ & $12 \mathrm{~b}$ & $215 b$ \\
\hline & L80 & $63 \mathrm{a}$ & $51 \mathrm{ab}$ & $13 \mathrm{ab}$ & $28 \mathrm{~b}$ & $12 \mathrm{a}$ & $20 \mathrm{~b}$ & $17 \mathrm{a}$ & $13 \mathrm{ab}$ & $218 \mathrm{ab}$ \\
\hline & L60 & $63 \mathrm{a}$ & $52 \mathrm{a}$ & $13 \mathrm{a}$ & $30 \mathrm{ab}$ & $12 \mathrm{a}$ & $20 \mathrm{~b}$ & $17 \mathrm{a}$ & $14 \mathrm{ab}$ & $221 a b$ \\
\hline & L40 & $63 \mathrm{a}$ & $52 \mathrm{a}$ & $13 \mathrm{a}$ & $32 \mathrm{a}$ & $11 \mathrm{a}$ & $20 \mathrm{~b}$ & $17 \mathrm{a}$ & $14 \mathrm{a}$ & $224 \mathrm{ab}$ \\
\hline & L20 & $63 \mathrm{a}$ & $52 \mathrm{a}$ & $13 \mathrm{a}$ & $33 \mathrm{a}$ & $11 \mathrm{a}$ & $20 \mathrm{~b}$ & $17 \mathrm{a}$ & $14 \mathrm{a}$ & $225 \mathrm{a}$ \\
\hline \multirow{5}{*}{$\begin{array}{l}2016- \\
2017\end{array}$} & CK & 64 a & $41 \mathrm{c}$ & $13 \mathrm{a}$ & $32 \mathrm{c}$ & $14 \mathrm{a}$ & $20 \mathrm{a}$ & $16 \mathrm{a}$ & $14 \mathrm{a}$ & $213 \mathrm{c}$ \\
\hline & L80 & 64 a & $42 \mathrm{~b}$ & $14 \mathrm{a}$ & $33 \mathrm{bc}$ & $15 \mathrm{a}$ & $19 \mathrm{ab}$ & $16 \mathrm{a}$ & $14 \mathrm{a}$ & $216 \mathrm{~b}$ \\
\hline & L60 & $64 \mathrm{a}$ & $42 \mathrm{~b}$ & $14 \mathrm{a}$ & $34 \mathrm{bc}$ & $15 \mathrm{a}$ & $19 \mathrm{ab}$ & $17 \mathrm{a}$ & $14 \mathrm{a}$ & $218 a b$ \\
\hline & L40 & 64 a & $43 \mathrm{a}$ & $14 \mathrm{a}$ & $35 \mathrm{ab}$ & $15 \mathrm{a}$ & $19 \mathrm{ab}$ & $17 \mathrm{a}$ & $14 \mathrm{a}$ & $220 \mathrm{a}$ \\
\hline & L20 & $64 \mathrm{a}$ & $43 \mathrm{a}$ & $14 \mathrm{a}$ & $36 \mathrm{a}$ & $15 \mathrm{a}$ & $18 \mathrm{~b}$ & $18 \mathrm{a}$ & $14 \mathrm{a}$ & $221 \mathrm{a}$ \\
\hline \multicolumn{2}{|r|}{$\mathrm{L}$} & 0 & $30.22 * * *$ & $9.688 * * *$ & $19.15^{* * *}$ & 1.00 & $11.17 * * *$ & $5.9 * *$ & $3.56^{*}$ & $11.4 * * *$ \\
\hline \multicolumn{2}{|r|}{$\mathrm{Y}$} & $10.71 * *$ & $3808.8^{* * *}$ & $36.13 * * *$ & $67.60 * * *$ & $142.3 * * *$ & $52.0 * * *$ & 0.08 & 1.13 & 2.36 \\
\hline \multicolumn{2}{|r|}{$\mathrm{L} \times \mathrm{Y}$} & 0 & 1.83 & 0.19 & 0.85 & 0.21 & 1.67 & 0.92 & $3.31 *$ & 0.34 \\
\hline
\end{tabular}

$\dagger$ Data followed by the same letter in a column indicate a nonsignificant difference among the treatments according to the LSD test $(\mathrm{P}=0.05)$

CK refers to the 'no shading' treatment (control), L80, L60, L40 and L20, refer to 80\%, 60\%, 40\% and $20 \%$ of the incident solar radiation, respectively. L, light control; Y, year. *, significance at the .05 level; **, significance at the .01 level; ***, significance at the .001 level

\section{Evapotranspiration and daily mean evapotranspiration of the winter wheat}

The evapotranspiration at each growing stage $\left(\mathrm{ET}_{\mathrm{gs}}\right)$ was affected $(\mathrm{p}<0.05)$ by the shading from the winter period to the mature period. ET $_{\mathrm{gs}}$ were affected $(\mathrm{p}<0.01)$ by the year except for the green stage, jointing stage, and filling stage (Table 3). And ETgs under different shading treatments were affected $(\mathrm{p}<0.01)$ by the growing stages $($ Table 4$)$.

Table 3. Analysis of variance on evapotranspiration and daily mean evapotranspiration of each growing stage as affected by light control and years

\begin{tabular}{c|c|c|c|c|c|c|c|c|c|c}
\hline & Factors & $\begin{array}{c}\text { Seeding } \\
\text { stage }\end{array}$ & $\begin{array}{c}\text { Tillering } \\
\text { stage }\end{array}$ & $\begin{array}{c}\text { Winter } \\
\text { period }\end{array}$ & $\begin{array}{c}\text { Green } \\
\text { stage }\end{array}$ & $\begin{array}{c}\text { Joining } \\
\text { stage }\end{array}$ & $\begin{array}{c}\text { Booting } \\
\text { stage }\end{array}$ & $\begin{array}{c}\text { Heading to } \\
\text { flowering }\end{array}$ & $\begin{array}{c}\text { Filling } \\
\text { stage }\end{array}$ & $\begin{array}{c}\text { Mature } \\
\text { period }\end{array}$ \\
\hline \multirow{2}{*}{$\mathrm{ET}_{\mathrm{gs}}$} & $\mathrm{L}$ & 2.22 & 1.41 & $10.83^{*}$ & $29.75^{* *}$ & $79.50^{* * *}$ & $8.59^{*}$ & $35.48^{* *}$ & $28.78^{* *}$ & $152.21 * * *$ \\
& $\mathrm{Y}$ & $184.06^{* * *}$ & $344.11^{* * *}$ & $81.05^{* * *}$ & 0.30 & 0.83 & $39.82^{* *}$ & $471.39 * * *$ & 5.46 & $233.20^{* * *}$ \\
\hline \multirow{2}{*}{$\mathrm{ET}_{\mathrm{dm}}$} & $\mathrm{L}$ & 0.86 & 1.51 & $9.43^{*}$ & $71.32^{* * *}$ & $807.61 * * *$ & $9.63 *$ & $74.56 * * *$ & $35.02 * *$ & 6.04 \\
& $\mathrm{Y}$ & $112.97 * * *$ & $344.21 * * *$ & 0.08 & $15.08^{*}$ & $197.24 * * *$ & $7.95 *$ & $1264.57 * * *$ & 5.23 & 0.55 \\
\hline
\end{tabular}

$\mathrm{ET}_{\mathrm{gs}}$, evapotranspiration of each growing stage; $\mathrm{ET}_{\mathrm{dm}}$, daily mean evapotranspiration of each growing stage; L, light control; $\mathrm{Y}$, year. *, significance at the .05 level; **, significance at the .01 level; ***, significance at the .001 level

The $\mathrm{ET}_{\mathrm{gs}}$ from 2015 to 2016 showed that the filling stage $>$ heading to flowering $>$ jointing stage $>$ booting stage $>$ wintering period $>$ mature stage under $\mathrm{CK}$ and L80 treatments, filling stage $>$ heading to flowering $>$ booting stage $>$ jointing stage $>$ mature stage $>$ wintering period under L60, L40, and L20 treatments, (Fig. 3, Table 4). It was similar from 2016 to 2017, except that the $\mathrm{ET}_{\mathrm{gs}}$ in the booting stage was higher than that in the heading to the flowering stage (Table 4). The water consumption of the winter wheat was primarily concentrated in the four growing stages, including the 
jointing, booting, heading to flowering and filling stages, accounting for $78.42 \%$ of the whole growth period, and the highest rate of water consumption was in the filling period, accounting for $27.34 \%$.

Table 4. Evapotranspiration and daily mean evapotranspiration of each growing stage

$\left(E T_{g s}, E T_{d m}, \mathrm{~mm}\right)$ of different shading treatments under different growing stages

\begin{tabular}{|c|c|c|c|c|c|c|c|c|c|c|c|}
\hline \multicolumn{2}{|r|}{ Factors } & \multicolumn{5}{|c|}{$\mathbf{E t}_{\mathrm{gs}}$} & \multicolumn{5}{|c|}{$\mathbf{E} \mathbf{T}_{\mathrm{dm}}$} \\
\hline $\mathbf{Y}$ & $\mathbf{G}$ & CK & L80 & L60 & L40 & L20 & CK & L80 & L60 & L40 & L20 \\
\hline \multirow{9}{*}{$\begin{array}{l}2015- \\
2016\end{array}$} & Seeding stage & $10.71 \mathrm{~h} \dagger$ & $11.01 \mathrm{f}$ & $12.12 \mathrm{~g}$ & $12.17 \mathrm{~h}$ & $12.89 \mathrm{~h}$ & $0.46 \mathrm{~h}$ & $0.47 \mathrm{f}$ & $0.52 \mathrm{~g}$ & $0.52 \mathrm{~g}$ & $0.56 \mathrm{~g}$ \\
\hline & Tillering stage & $16.64 \mathrm{~g}$ & $17.25 \mathrm{e}$ & $18.28 \mathrm{f}$ & $17.79 \mathrm{~g}$ & $18.70 \mathrm{~g}$ & $0.47 \mathrm{~h}$ & $0.49 \mathrm{f}$ & $0.52 \mathrm{~g}$ & $0.50 \mathrm{~g}$ & $0.53 \mathrm{~g}$ \\
\hline & Wintering period & $33.51 \mathrm{e}$ & $32.70 \mathrm{~d}$ & $32.04 \mathrm{e}$ & $30.09 \mathrm{f}$ & $29.35 f$ & $0.67 \mathrm{~g}$ & $0.64 \mathrm{f}$ & $0.61 \mathrm{~g}$ & $0.57 \mathrm{~g}$ & $0.56 \mathrm{~g}$ \\
\hline & Green stage & $16.15 \mathrm{~g}$ & $14.18 \mathrm{ef}$ & $13.12 \mathrm{~g}$ & $11.52 \mathrm{~h}$ & $11.09 \mathrm{~h}$ & $1.34 \mathrm{f}$ & $1.09 \mathrm{e}$ & $1.00 \mathrm{f}$ & $0.88 \mathrm{f}$ & $0.85 \mathrm{f}$ \\
\hline & Jointing stage & $93.24 \mathrm{c}$ & $79.42 \mathrm{c}$ & $58.40 \mathrm{~d}$ & $54.13 d$ & $57.45 \mathrm{~d}$ & $3.33 \mathrm{~d}$ & $2.63 \mathrm{~d}$ & $1.94 \mathrm{e}$ & $1.69 \mathrm{e}$ & $1.74 \mathrm{e}$ \\
\hline & Booting stage & $81.18 \mathrm{~d}$ & $75.24 \mathrm{c}$ & $70.19 \mathrm{c}$ & $62.96 \mathrm{c}$ & $59.92 \mathrm{c}$ & $7.38 \mathrm{~b}$ & $6.27 \mathrm{~b}$ & $5.84 \mathrm{~b}$ & $5.72 b$ & $5.44 \mathrm{~b}$ \\
\hline & Heading to flowering & $150.98 \mathrm{~b}$ & $121.83 \mathrm{~b}$ & $106.42 \mathrm{~b}$ & $106.26 \mathrm{~b}$ & $100.88 b$ & $6.86 \mathrm{c}$ & $6.09 \mathrm{~b}$ & $5.32 \mathrm{c}$ & $5.31 \mathrm{c}$ & $5.04 \mathrm{c}$ \\
\hline & Filling stage & $180.97 \mathrm{a}$ & $139.51 \mathrm{a}$ & $129.95 \mathrm{a}$ & $119.13 \mathrm{a}$ & $116.83 a$ & $11.3 \mathrm{a}$ & $8.20 \mathrm{a}$ & $7.64 \mathrm{a}$ & $7.00 \mathrm{a}$ & $6.87 \mathrm{a}$ \\
\hline & Mature period & $29.57 \mathrm{f}$ & $32.15 \mathrm{e}$ & $33.94 \mathrm{e}$ & $48.60 \mathrm{e}$ & $52.78 \mathrm{e}$ & $2.46 \mathrm{e}$ & $2.67 \mathrm{c}$ & $2.42 \mathrm{~d}$ & $4.05 \mathrm{~d}$ & $4.79 \mathrm{~d}$ \\
\hline \multirow{9}{*}{$\begin{array}{l}2016- \\
2017\end{array}$} & Seeding stage & $15.94 \mathrm{~h}$ & $16.21 \mathrm{~h}$ & $16.21 \mathrm{f}$ & $16.16 \mathrm{~g}$ & $16.56 \mathrm{~g}$ & $0.72 \mathrm{f}$ & $0.7 \mathrm{e}$ & $0.7 \mathrm{~d}$ & $0.7 \mathrm{f}$ & $0.72 \mathrm{f}$ \\
\hline & Tillering stage & $23.89 \mathrm{~g}$ & $23.88 \mathrm{~g}$ & $23.88 \mathrm{e}$ & $23.96 f$ & $24.13 \mathrm{e}$ & $0.68 \mathrm{f}$ & $0.68 \mathrm{e}$ & $0.68 \mathrm{~d}$ & $0.68 \mathrm{f}$ & $0.69 \mathrm{f}$ \\
\hline & Winteringperiod & $29.34 \mathrm{f}$ & $28.26 f$ & $25.12 \mathrm{e}$ & $23.36 \mathrm{f}$ & $22.12 \mathrm{f}$ & $0.72 \mathrm{f}$ & $0.67 \mathrm{e}$ & $0.6 \mathrm{~d}$ & $0.54 \mathrm{f}$ & $0.51 \mathrm{f}$ \\
\hline & Green stage & $17.04 \mathrm{~h}$ & $14.82 \mathrm{~h}$ & $12.44 \mathrm{~g}$ & $10.69 \mathrm{~h}$ & $9.98 \mathrm{~d}$ & $1.31 \mathrm{e}$ & $1.06 \mathrm{e}$ & $0.89 \mathrm{~cd}$ & $0.76 \mathrm{f}$ & $0.71 \mathrm{f}$ \\
\hline & Jointing stage & $95.98 \mathrm{c}$ & $81.79 \mathrm{c}$ & $54.9 \mathrm{c}$ & $51.13 \mathrm{~d}$ & $50.2 \mathrm{~d}$ & $2.8 \mathrm{~d}$ & $2.48 \mathrm{~d}$ & $1.61 \mathrm{~cd}$ & $1.46 \mathrm{e}$ & $1.39 \mathrm{e}$ \\
\hline & Booting stage & $127.01 \mathrm{~b}$ & $109.57 \mathrm{~b}$ & $106.57 \mathrm{~b}$ & $88.63 b$ & $83.73 b$ & $9.07 \mathrm{~b}$ & $7.3 b$ & $7.1 \mathrm{a}$ & $5.91 \mathrm{~b}$ & $5.58 \mathrm{~b}$ \\
\hline & Heading to flowering & $83.99 \mathrm{~d}$ & $64.28 \mathrm{~d}$ & $53.53 \mathrm{c}$ & $49.28 \mathrm{e}$ & $48.67 \mathrm{~d}$ & $4.2 \mathrm{c}$ & $3.38 \mathrm{c}$ & $2.82 \mathrm{~b}$ & $2.59 \mathrm{~d}$ & $2.7 \mathrm{~d}$ \\
\hline & Filling stage & $209.16 \mathrm{a}$ & $160.01 \mathrm{a}$ & $139.74 a$ & $120.44 \mathrm{a}$ & $118.68 \mathrm{a}$ & $13.07 \mathrm{a}$ & $9.41 \mathrm{a}$ & $8.22 \mathrm{a}$ & $7.08 \mathrm{a}$ & $6.98 \mathrm{a}$ \\
\hline & Mature period & $41.85 \mathrm{e}$ & $45.56 \mathrm{e}$ & $42.88 \mathrm{~d}$ & $61.01 \mathrm{c}$ & $63.97 \mathrm{c}$ & $2.82 \mathrm{~d}$ & $2.85 \mathrm{~cd}$ & $2.52 b c$ & $3.59 \mathrm{c}$ & $3.55 \mathrm{c}$ \\
\hline & $\mathrm{G}$ & $* * *$ & $* * *$ & $* * *$ & $* * *$ & $* * *$ & $* * *$ & $* * *$ & $* * *$ & $* * *$ & **** \\
\hline & $\mathrm{Y}$ & $* * *$ & $* * *$ & 0.677 & $* * *$ & $* * *$ & $0.001^{* *}$ & 0.924 & 0.496 & $* * *$ & $* * *$ \\
\hline & $G \times Y$ & $* * *$ & $* * *$ & $* * *$ & $* * *$ & $* * *$ & $* * *$ & $* * *$ & $* * *$ & $* * *$ & $* * *$ \\
\hline
\end{tabular}

$\dagger$ Data followed by the same letter in a column indicate a nonsignificant difference among the treatments according to the LSD test $(\mathrm{P}=0.05)$

CK refers to the 'no shading' treatment (control), L80, L60, L40 and L20, refer to 80\%,60\%, $40 \%$ and $20 \%$ of the incident solar radiation, respectively. $\mathrm{ET}_{\mathrm{gs}}$, evapotranspiration of each growing stage; $\mathrm{ET}_{\mathrm{dm}}$, daily mean evapotranspiration of each growing stage; $\mathrm{G}$, growing stage; $\mathrm{Y}$, year. *, significance at the .05 level; **, significance at the .01 level; ***, significance at the .001 level

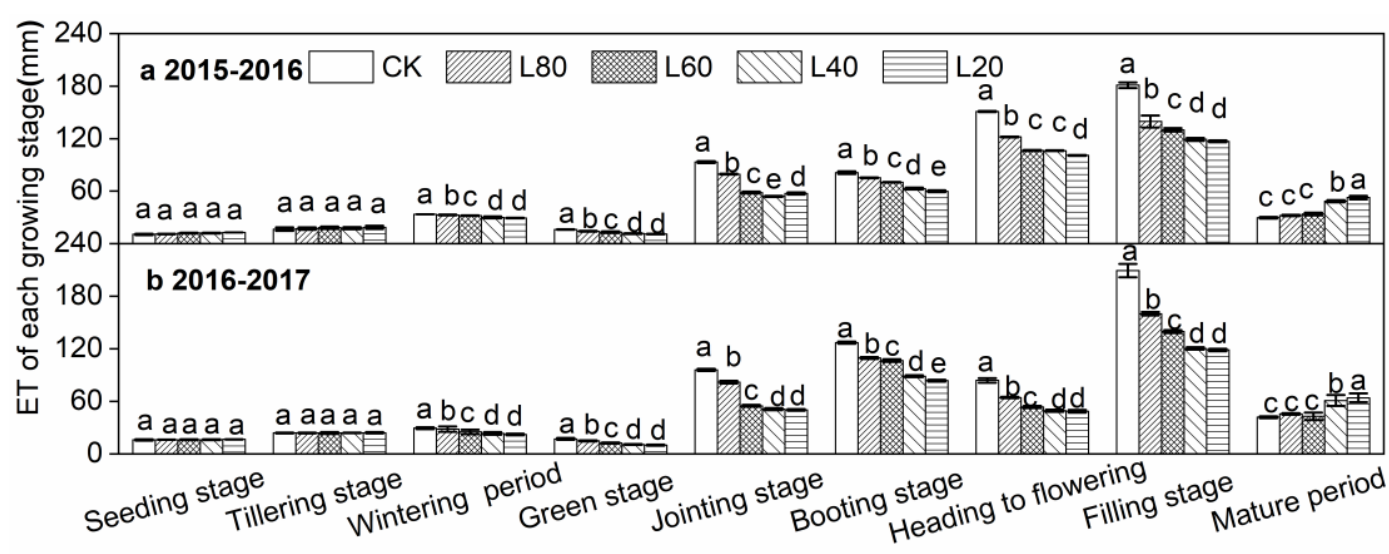

Figure 3. Evapotranspiration of each growing stage ( $\left.E T_{g s}\right)$ for the shading treatments. $C K$ refers to the 'no shading' treatment (control), L80, L60, L40 and L20, refer to $80 \%, 60 \%, 40 \%$ and $20 \%$ of the incident solar radiation, respectively. Data are means of four replicates.

Vertical bars indicate standard error. The same letters within each growing stage in the same year are not significantly different at $P<0.05$ 
The ET $\mathrm{gs}_{\mathrm{gs}}$ decreased gradually as the degree of shading increased in each treatment from the wintering period to the filling stage. There were significant differences in water consumption among the treatments in jointing, booting, heading to the flowering, and filling stages. The ET $\mathrm{gs}_{\mathrm{gs}}$ had significant differences among the CK, L80, and L60 treatments, while there were no significant differences among the L60, L40, and L20 treatments. Compared with the CK, the $\mathrm{ET}_{\mathrm{gs}}$ of the L80, L60, L40, and L20 treatments from the jointing to the filling stages decreased by $16.09 \%, 27.15 \%, 32.04 \%$, and $33.30 \%$, respectively. When compared with the CK, the maximum decrease in the $\mathrm{ET}_{\mathrm{gs}}$ for the L80, L60, L40, and L20 treatments was $22.91 \%, 28.19 \%, 34.17 \%$, and $35.44 \%$ during the filling period, respectively. However, in the mature stage, the ET of the winter wheat increased gradually with the increase in the intensity of shading.

The daily mean evapotranspiration of each growing stage $\left(\mathrm{ET}_{\mathrm{dm}}\right)$ was significantly affected by shading treatments $(\mathrm{p}<0.05)$ from the winter period to the filling stage. $\mathrm{ET}_{\mathrm{dm}}$ was affected $(\mathrm{p}<0.05)$ by the year except for the winter period, filling stage, and mature period (Table 3). And $\mathrm{ET}_{\mathrm{dm}}$ under different shading treatments were affected $(\mathrm{p}<0.01)$ by the growing stages $($ Table 4$)$. The $\mathrm{ET}_{\mathrm{dm}}$ in each growing stage showed that the filling stage $>$ booting stage $>$ heading to flowering $>$ mature stage $>$ jointing stage in two years experiments (Fig. 4; Table 4). The $\mathrm{ET}_{\mathrm{dm}}$ was larger from the booting to the filling stages than that in the other growing stages. The average $\mathrm{ET}_{\mathrm{dm}}$ of all the treatments from the booting stage to the filling stage was 2.12 times greater than that of the whole growing stages. The maximum of the $\mathrm{ET}_{\mathrm{dm}}$ in the filling period was $12.51 \mathrm{~mm}$, while the average $\mathrm{ET}_{\mathrm{dm}}$ of all the treatments was 2.59 times that of the whole growth period.

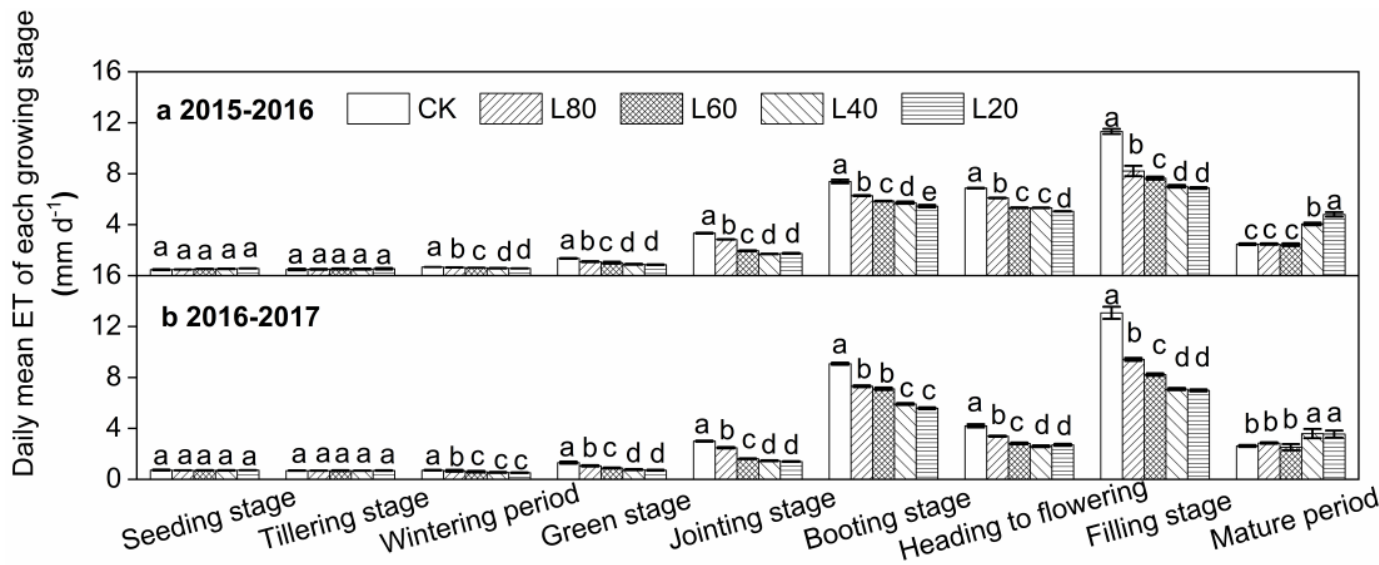

Figure 4. Daily mean evapotranspiration of each growing stage $\left(E T_{d m}\right)$ for the shading treatments. Data are means of four replicates. CK refers to the 'no shading' treatment (control),

L80, L60, L40 and L20, refer to $80 \%, 60 \%, 40 \%$ and $20 \%$ of the incident solar radiation, respectively. Vertical bars indicate standard error. The same letters within each growing stage in the same year are not significantly different at $P<0.05$

Except for the mature period, the $\mathrm{ET}_{\mathrm{dm}}$ decreased with the increase in the shading intensity with significant differences among the different treatments that were the same as the $\mathrm{ET}_{\mathrm{dm}}$ during the same growing stage. The $\mathrm{ET}_{\mathrm{dm}}$ for the L80, L60, L40 and L20 treatments decreased by $19.80 \%, 23.31 \%, 27.69 \%$, and $30.64 \%$, respectively, from the 
booting to the filling stages and decreased by $27.45 \%, 32.42 \%, 38.04 \%$, and $39.24 \%$ in the filling stage compared with the $\mathrm{CK}$, respectively.

\section{Typical sunny day evapotranspiration of the winter wheat at different growing stages}

The ET of a typical sunny day $\left(\mathrm{ET}_{\mathrm{ts}}\right)$ was divided into the ET of the daytime (from 8:00 to 20:00, $\mathrm{ET}_{\mathrm{d}}$ ) and nighttime (from 20:00 to 8:00 the next day, $\mathrm{ET}_{\mathrm{n}}$ ). Figure 5 shows the natural SRI and $2 \mathrm{~h}$ ET $\left(\mathrm{ET}_{2 \mathrm{~h}}\right)$ of each treatment on a typical sunny day in each growth period from 2015 to 2016. During the daytime, the ET $2 \mathrm{~h}$ changed roughly in a parabolic trend, first increasing and then decreasing, and the change in the trend was the same as that of the solar radiation.

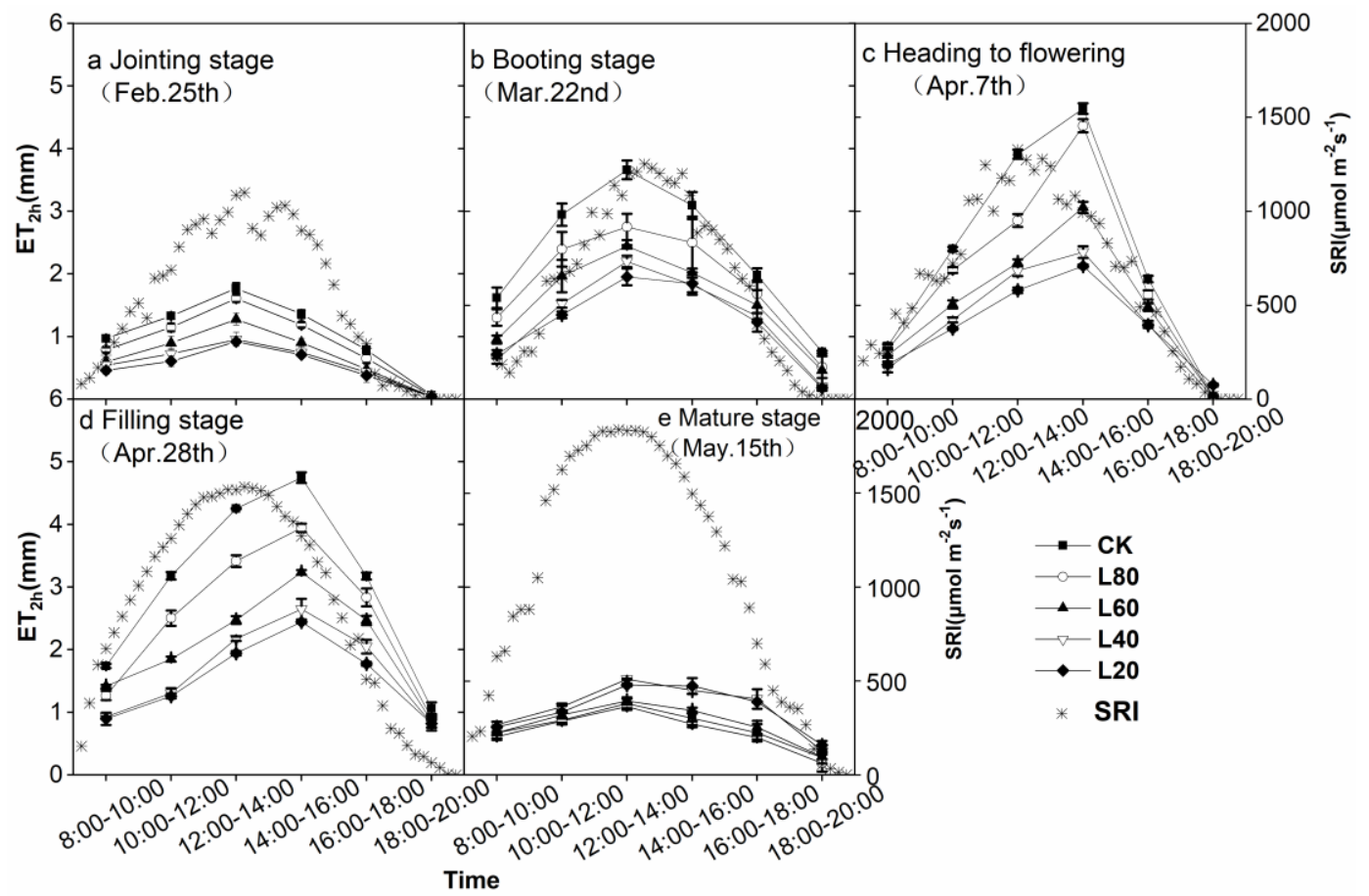

Figure 5. Evapotranspiration of $2 h\left(E T_{2 h}\right)$ of the winter wheat and solar radiation intensity (SRI) from 8:00 to 20:00 on typical sunny days in different growing stages (jointing stage, a, booting stage, $b$, heading to flowering, $c$, filling stage, $d$, mature stage, $e$ ). $C K$ refers to the "no shading' treatment (control), L80, L60, L40 and L20, refer to 80\%, 60\%, 40\% and $20 \%$ of the incident solar radiation, respectively. Data are means of four replicates. The data were measured on February 25th, March 22nd, April 7th, April 28th and May 15th, 2016

Except for the mature stage (Fig. 5e), the $\mathrm{ET}_{2 \mathrm{~h}}$ in each growing stage increased gradually in parallel with the increase in the SRI (Fig. 5). The growing stage radiation intensity increased gradually over time, peaking at approximately 13:00. The $\mathrm{ET}_{2 \mathrm{~h}}$ peak in the jointing and booting stages was between 12:00 and 14:00, which was the same as the maximum radiation, while in the heading to the flowering and filling growing stages, the peak was between 14:00 and 16:00. The $\mathrm{ET}_{2 \mathrm{~h}}$ rapidly increased after 10:00 and rapidly decreased after 16:00.

The $\mathrm{ET}_{\mathrm{d}}, \mathrm{ET}_{\mathrm{n}}$, and $\mathrm{ET}_{\mathrm{ts}}$ of the wheat on typical sunny days in different growing stages are shown in Figure 6. The ET ts from the booting to the filling stages (Fig. 6b, $c$ and $d$ ) was larger than that in the other growing stages (Fig. $6 a$ and $e$ ), which was 
consistent with that of the $\mathrm{ET}_{\mathrm{d}}$. The $\mathrm{ET}_{\mathrm{d}}$ of the wheat showed that the filling stage $>$ heading to flowering stage $>$ booting stage $>$ jointing stage $>$ mature stage. The proportion of the $\mathrm{ET}_{\mathrm{n}}$ to $\mathrm{ET}_{\mathrm{ts}}$ at the jointing and booting stages (Fig. $6 a$ and $b$ ) was approximately $10 \%$, and it increased from $12 \%$ to $19 \%$ at the heading to the flowering and filling stages (Fig. $6 c$ and $d$ ), respectively. The proportion of the $\mathrm{ET}_{\mathrm{d}}$ to $\mathrm{ET}_{\mathrm{ts}}$ was more than $80 \%$ in all the growing stages, which indicated that the $\mathrm{ET}_{\mathrm{d}}$ was the primary part of the $\mathrm{ET}_{\mathrm{ts}}$. Except the mature stage, the $\mathrm{ET}_{\mathrm{n}}$ from the jointing to the filling stages of the L80, L60, L40, and L20 treatments decreased by $10.37 \%, 15.33 \%, 24.06 \%$, and $23.92 \%$, respectively, compared with the CK, which was significantly smaller than that of the daytime.

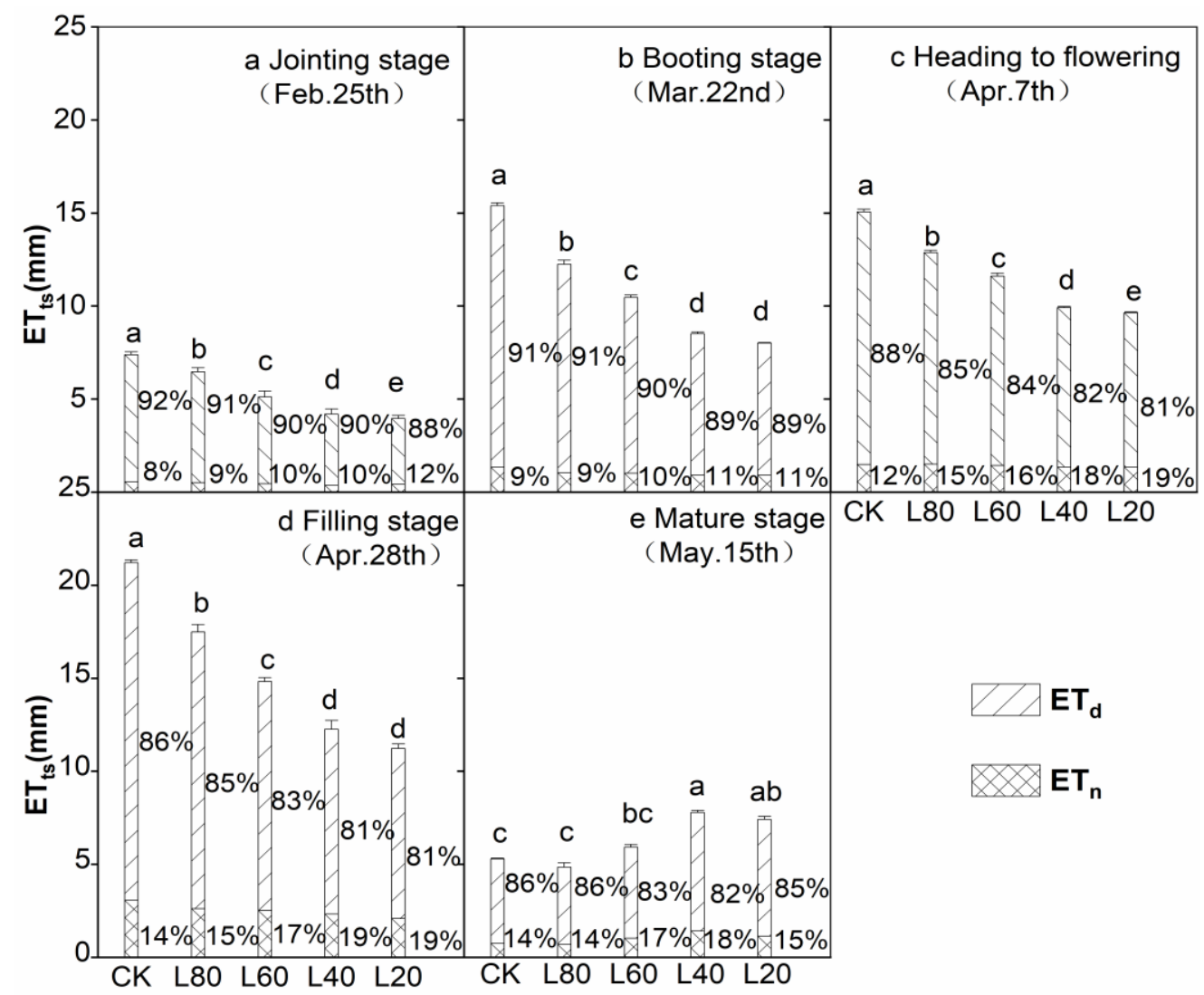

Figure 6. Typical sunny day evapotranspiration $\left(E T_{t s}\right)$, evapotranspiration of day $\left(E T_{d}\right)$ and night $\left(E T_{n}\right)$ of winter wheat on typical sunny days of each growing stage (jointing stage, $a$, booting stage, $b$, heading to flowering, $c$, filling stage, $d$, mature stage, $e$ ). The data were measured on February 25th, March 22nd, April 7th, April 28th and May 15th, 2016. Data are means of four replicates. CK refers to the 'no shading' treatment (control), L80, L60, L40 and L20, refer to $80 \%, 60 \%, 40 \%$ and $20 \%$ of the incident solar radiation, respectively. Vertical bars indicate standard error. The same letters within each growing stage are not significantly different at $P<0.05$

From the jointing to the filling stages, the $\mathrm{ET}_{\text {ts }}$ decreased with the increase in the shading degree. The difference of the $\mathrm{ET}_{\mathrm{ts}}$ among the CK, L20, and L40 treatments was significant, while that between the L60 and L80 treatments was not significant at the booting and filling stages. At the mature period (Fig. 6e), the $\mathrm{ET}_{\mathrm{ts}}$ increased with the increase in the shading degree. 


\section{Effects of shading on the grain yield and WUE}

The grain yield $(\mathrm{GY})$ was affected $(\mathrm{p}<0.001)$ by both shading and year. And, there was significant interaction $(p<0.001)$ of shading and year. Grain yield compomers kernel number per spike (KNPS), spike number, 1000-grain weight were affected $(\mathrm{p}<0.001)$ by both shading and year (Table 5).

Table 5. Effect of Shading on the kernel number per stem (KNPS), spike number (spike no.),

1000-grain weight, grain yield (GY), dry matter accumulation (DMA), whole

evapotranspiration (WET), water use efficiency (WUE) and harvest index (HI) of the winter wheat in 2015-2016 and 2016-2017

\begin{tabular}{|c|c|c|c|c|c|c|c|c|c|}
\hline Years & Treatments & KNPS & $\begin{array}{c}\text { Spike no. } \\
\left(10^{4} \mathbf{h a}^{-1}\right)\end{array}$ & $\begin{array}{l}\text { 1000-grain } \\
\text { weight (g) }\end{array}$ & $\begin{array}{c}\mathbf{G Y} \\
\left(\mathrm{kg} \mathrm{ha}^{-1}\right)\end{array}$ & $\begin{array}{c}\text { DMA } \\
\left(\text { g stem }^{-1}\right)\end{array}$ & $\begin{array}{l}\text { HI } \\
(\%)\end{array}$ & $\begin{array}{l}\text { WET } \\
(\mathbf{m m})\end{array}$ & $\begin{array}{c}\text { WUE } \\
\left(\mathrm{kg} \mathrm{ha}^{-1} \mathbf{m m}^{-1}\right)\end{array}$ \\
\hline \multirow{5}{*}{$\begin{array}{c}2015- \\
2016\end{array}$} & CK & $42.73 \mathrm{a} \dagger$ & $610.33 a$ & $43.93 \mathrm{a}$ & $11454.3 \mathrm{a}$ & $3.13 a$ & $42.17 \mathrm{a}$ & $613.01 \mathrm{a}$ & $18.69 a$ \\
\hline & L80 & $40.88 \mathrm{~b}$ & $554.19 \mathrm{~b}$ & $42.300 \mathrm{~b}$ & $9583.85 \mathrm{~b}$ & $2.63 b$ & $44.38 \mathrm{a}$ & $518.26 \mathrm{~b}$ & $18.49 \mathrm{a}$ \\
\hline & L60 & $26.44 \mathrm{c}$ & $481.67 \mathrm{c}$ & $34.40 \mathrm{e}$ & $4761.52 \mathrm{c}$ & $1.90 \mathrm{c}$ & $35.13 b$ & $479.60 \mathrm{c}$ & $9.94 b$ \\
\hline & L40 & $25.24 d$ & $373.92 d$ & $39.26 \mathrm{~d}$ & $3705.54 d$ & $1.58 \mathrm{~cd}$ & $35.05 \mathrm{~b}$ & $462.74 d$ & $8.01 \mathrm{c}$ \\
\hline & L20 & $24.87 \mathrm{~d}$ & $292.35 \mathrm{e}$ & $40.31 \mathrm{c}$ & $2955.17 \mathrm{e}$ & $1.46 \mathrm{~d}$ & $33.69 \mathrm{~b}$ & $459.91 \mathrm{e}$ & $6.43 d$ \\
\hline \multirow{8}{*}{$\begin{array}{c}2016- \\
2017\end{array}$} & CK & $49.56 a$ & $591.16 \mathrm{a}$ & $45.78 \mathrm{a}$ & $13412.2 \mathrm{a}$ & $3.96 \mathrm{a}$ & $46.50 \mathrm{a}$ & $644.20 \mathrm{a}$ & $20.83 a$ \\
\hline & L80 & $46.22 \mathrm{~b}$ & $536.87 \mathrm{~b}$ & $44.55 b$ & $11052.7 \mathrm{~b}$ & $3.67 \mathrm{~b}$ & $48.75 \mathrm{a}$ & $544.37 \mathrm{~b}$ & $20.30 \mathrm{a}$ \\
\hline & L60 & $30.21 \mathrm{c}$ & $466.68 \mathrm{c}$ & $38.97 \mathrm{~d}$ & $5495.57 \mathrm{c}$ & $2.52 \mathrm{c}$ & $38.75 b$ & $475.28 \mathrm{c}$ & $11.57 \mathrm{~b}$ \\
\hline & L40 & $29.14 d$ & $360.69 d$ & $39.45 \mathrm{c}$ & $4146.11 d$ & $2.10 \mathrm{~d}$ & $37.75 b c$ & $444.67 d$ & $9.32 \mathrm{c}$ \\
\hline & L20 & $27.33 d$ & $285.63 \mathrm{e}$ & $38.65 \mathrm{~d}$ & $3016.16 \mathrm{e}$ & $1.89 \mathrm{e}$ & $35.00 \mathrm{c}$ & $438.02 \mathrm{~d}$ & $6.89 \mathrm{~d}$ \\
\hline & $\mathrm{L}$ & $2538 * * *$ & $3029.0 * * *$ & $611.1 * * *$ & $7367 * * *$ & $348.53 * * *$ & $52.4 * * *$ & $607.9 * * *$ & $2274.45 * * *$ \\
\hline & $\mathrm{Y}$ & $665.9 * * *$ & $51.32 * * *$ & $64.01 * * *$ & $460.1 * * *$ & $306.45 * * *$ & $23.21 * * *$ & 0.92 & $163.22 * * *$ \\
\hline & $\mathrm{L} \times \mathrm{Y}$ & $18.6^{* * * *}$ & 0.69 & $46.44 * * *$ & $63.00 * * *$ & $7.72 * * *$ & 0.69 & $16.56^{* * *}$ & $6.16^{* * *}$ \\
\hline
\end{tabular}

$\dagger$ Data followed by the same letter in a column indicate a nonsignificant difference among the treatments according to the LSD test $(\mathrm{P}=0.05)$

CK refers to the 'no shading' treatment (control), L80, L60, L40 and L20, refer to 80\%, 60\%, 40\% and $20 \%$ of the incident solar radiation, respectively. Data are means of four replicates. L, light control; Y, year. *, significance at the .05 level; **, significance at the .01 level; ***, significance at the .001 level

There were significant differences in the wheat GY, KNPS, spike number and 1000grain weight among the treatments, and the yield decreased gradually with the increase in the shading degree. Compared with the CK, the yields of the L80, L60, L40, and L20 treatments decreased by $16.96 \%, 58.73 \%, 68.37 \%$ and $75.86 \%$, respectively. The yield decreased by more than $50 \%$ when the shading degree exceeded $40 \%$. The KNPS and spike number decreased with the increase in the shading degree. The 1000-grain weight decreased first and then increased with the increase in the shading degree, and the minimum value was observed in the L60 treatment.

Dry matter accumulation (DMA) and harvest index (HI) were affected $(\mathrm{p}<0.001)$ by both light control and year. The DMA decreased gradually with the increase in the shading degree. There were significant differences for the DMA among the CK, L80 and L60 treatments but no significant difference between the L40 and L20 treatments from 2015 to 2016. With the increase in the shading degree, the HI had increased first and then decreased (Table 5). The largest HI was 44.38\% in L80 treatment.

The whole growth period ET (WET) and water use efficiency (WUE) were affected $(\mathrm{P}<0.001)$ by light control (Table 5). The WET and WUE were significant interactions $(\mathrm{p}<0.001)$ of light control and year. However, WET was not affected $(\mathrm{P}>0.05)$ by year. The WET decreased gradually with the increase in the shading degree. Except for the L40 and L20 treatments in 2017, there were significant differences among the other 
treatments. With the increase in the shading degree, the WET of the L80, L60, L40 and L20 treatments decreased by $15.48 \%, 24.00 \%, 27.74 \%$ and $28.49 \%$, respectively, relative to the $\mathrm{CK}$, and the reduction in the WET between the treatments was not obvious when the light was shaded to less than $40 \%$ of the full radiation.

The WUE decreased gradually with the increase in the shading degree, and the difference of the WUE was not significant between the CK and L20 treatment, but the WUE differed significantly among the other treatments. The WUE with shading over $40 \%$ of the full radiation decreased greatly. Compared with the CK treatment, the WUE of the L80, L60, L40 and L20 treatments decreased by $1.80 \%, 45.64 \%, 56.20 \%$, and $66.26 \%$, respectively.

Figure 7 shows the fitting curve and equation of the yield, WET and water use efficiency with the natural light transmission degree (NLTD). The GY, WET and WUE all had a close-fitting relationship with the NLTD. The relationship between the yield and NLTD is the "S" curve (Fig. 7a). When the NLTD was less than $60 \%$, there was a relatively flat period. The yield increased rapidly when the NLTD was greater than 0.6 and slowed when the transmittance was more than 0.8 .

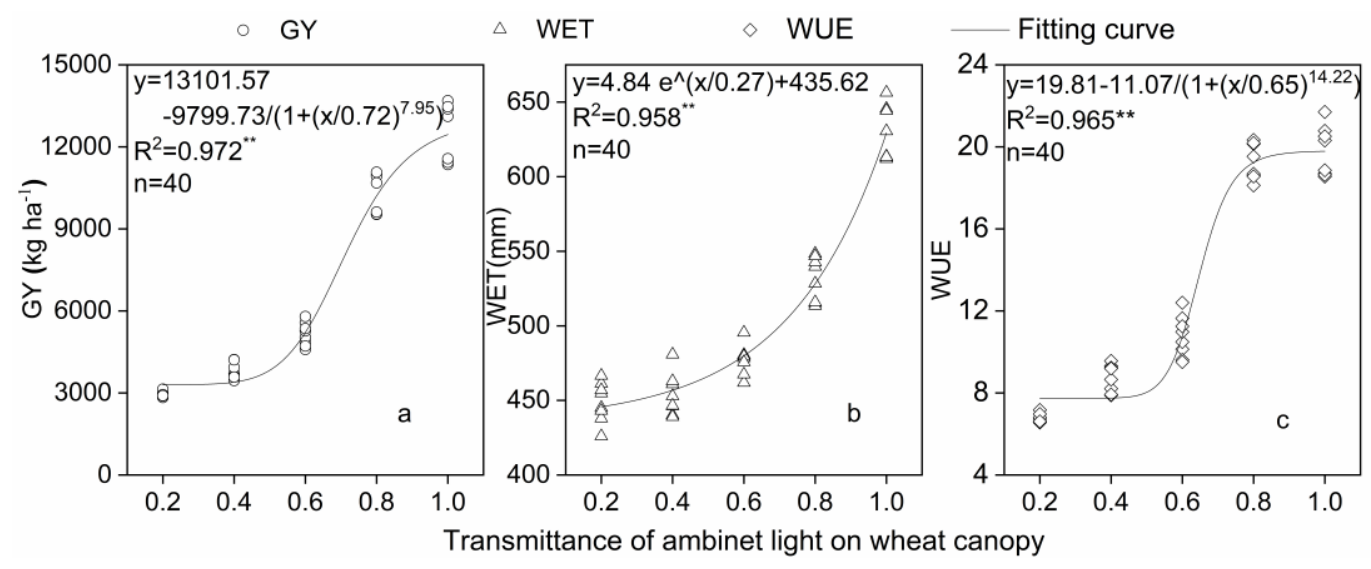

Figure 7. Regression analyses of the grain yield (GY, a), whole evapotranspiration (WET, $b$ ) and water use efficiency (WUE, $c$ ) with the transmittance of ambient light on the wheat canopy. **Significance at the $1 \%(P=0.01)$ level

The relationship between the WET and NLTD was fitted using an exponential function $($ Fig. $7 b)$. The growth rate of the WET increased in parallel with the increase in the NLTD. The WET increased slowly with the NLTD of 0.6 and increased approximately linearly with an NLTD of more than 0.8 . The relationship between the WUE and NLTD was fitted by the "S" curve (Fig. 7c). When the NLTD was less than 0.6 , the WUE increased very slowly, and then the WUE increased rapidly in parallel with the NLTD from 0.6 to 0.8 . Finally, when the NLTD was more than 0.8 , the WUE also increased very slowly.

\section{Discussion}

Experiment pots near to each other $(25 \mathrm{~cm})$ reduced the shading effect on temperature and $\mathrm{RH}$ (Table 1). Compared with the $\mathrm{CK}$, the average temperature decreased by $1,1.6,1.6$, and $1.7^{\circ} \mathrm{C}$ under the L80, L60, L40 and L20 treatment, 
respectively. While, the average $\mathrm{RH}$ increased by $1.3,1.9,2.6$ and $2.9 \%$ respectively. Therefore, solar radiation became the main factor in determining winter wheat growth and water consumption.

Shading decreased light intensity. Winter wheat photosynthesis time was prolonged to get enough solar radiation to complete winter wheat vegetative and reproductive growth (Yu and Wang, 2010). Phenological stages delayed and growth period prolonged by shading. The difference in phenological stages between treatments gradually increased and got stable after the booting period. Since the radiation amount before the booting period was relatively small, the shading had a greater influence on crop growth. And the later phenological stages radiation amount increased to accumulate enough crop substances (Fig. $1 a$ and $d$ ). With the growth of wheat, the temperature and the radiation increased gradually (Fig. $1 a, b, d$ and $e$ ). The increase in temperature and radiation causes an increase in crop water consumption (Miralles et al., 2011; Sorrentino et al., 1997). Compared with CK treatment, days of mature period under shading treatments condition delayed to get a higher temperature and more energy, it caused ET to increase. As, $\mathrm{ET}_{\mathrm{gs}}, \mathrm{ET}_{\mathrm{dm}}, \mathrm{ET}_{\mathrm{ts}}$ increased with shading degree increased in Figures 3, 4, 5e, and $6 e$. The extension of growth time was prolonged and the shading treatment was mainly prolonged at the early stages of winter wheat (Table 2). To reduce days prolonged by shading, shading should after the booting stage.

With the growth of wheat, solar radiation and temperature was gradually increasing. The ET $\mathrm{gs}_{\mathrm{gs}}, \mathrm{ET}_{\mathrm{dm}}, \mathrm{ET}_{\mathrm{ts}}$ and WET (except for the mature period) gradually decreased as the shading degree increased (Figs. 3, 4, 5, and 6.), and the difference was significant. The larger $\mathrm{ET}_{\mathrm{gs}}, \mathrm{ET}_{\mathrm{dm}}$ and $\mathrm{ET}_{\mathrm{ts}}$ were concentrated from the booting to the filling stages. The ET $\mathrm{gs}_{\mathrm{gs}}$ indicated water consumption intensity. Under supplemental irrigation showed winter wheat water demand law. Booting stage to filling stage is also a critical period of water requirement for wheat (Zhang et al., 2011; Zheng et al., 2014; Zhou et al., 2018). Irrigating during this period can increase the weight of 1000 kernels, crop yield and water use efficiency (Dandan et al., 2013; Zhou et al., 2018). Shading from booting to the filling stages can reduce more ET, while short time shading after booting also has less effect on the growth period.

Winter wheat ET of different growing stages reflects the distribution of water consumption, and ET in typical sunny weather reflects the water consumption potential. Shading degree affects the efficiency of ET in winter wheat, which better reflects the water-saving efficiency of shading (Table 6). Water-saving rates higher than shading rates were observed in treatment L80 from the heading stage to the filling stage in the growing period, and from the booting stage to the filling stage under typical sunny weather conditions. The reduction of radiation during rainy days diminished the shade water-saving efficiency. The increase in shading degrees under other treatments also led to a decrease in water-saving efficiency.

Solar radiation has a greater impact on wheat ET. The ET increased rapidly at daybreak and decreased rapidly at sunset (Fig. 5). ET $_{\mathrm{d}}$ accounted for more than $80 \%$ of the $\mathrm{ET}_{\mathrm{ts}}\left(\right.$ Fig. 6 ), while $\mathrm{ET}_{\mathrm{n}}$ in each growth period had little change. Because light is a signal for stomatal movement in the absence of water stress, and stomatal regulation is the most important way for plants to adjust their transpiration rate ( $\mathrm{Yu}$ and Wang, 2010). In day time $6 \mathrm{~h}$ of ET accounted for more than $70 \%$ of the $\mathrm{ET}_{\mathrm{d}}$. The peak photosynthetic rate of the wheat was from 10:00 am to 12:00 pm (Mu et al., 2009). To improve the water use efficiency, 11:00 to 17:00 can be selected as the daytime light control period by shading. 
Table 6. Shading effect on winter wheat water reduced rate (\%) of growing period and typical sunny day under the different treatments

\begin{tabular}{c|c|c|c|c|c|c|c|c}
\hline & Treatment & $\begin{array}{c}\text { Wintering } \\
\text { period }\end{array}$ & $\begin{array}{c}\text { Green } \\
\text { stage }\end{array}$ & $\begin{array}{c}\text { Jointing } \\
\text { stage }\end{array}$ & $\begin{array}{c}\text { Booting } \\
\text { stage }\end{array}$ & $\begin{array}{c}\text { Heading to } \\
\text { flowering }\end{array}$ & $\begin{array}{c}\text { Filling } \\
\text { stage }\end{array}$ & $\begin{array}{c}\text { Mature } \\
\text { period }\end{array}$ \\
\hline \multirow{3}{*}{$\begin{array}{c}\text { Growing } \\
\text { period }\end{array}$} & L80 & 3.05 & 12.63 & 14.80 & 10.53 & 21.39 & 23.20 & -8.79 \\
& L60 & 9.38 & 22.90 & 40.08 & 14.81 & 32.89 & 30.69 & -13.62 \\
& L40 & 15.31 & 32.98 & 44.34 & 26.33 & 35.47 & 38.29 & -55.06 \\
\multirow{4}{*}{ Typical } & 120 & 18.53 & 36.40 & 43.04 & 30.13 & 37.62 & 39.35 & -65.66 \\
\hline sunny day & L80 & 3.95 & 14.64 & 16.28 & 20.41 & 23.98 & 22.34 & 8.41 \\
& L60 & 10.16 & 24.09 & 32.11 & 32.00 & 34.14 & 31.09 & -11.92 \\
& L40 & 17.11 & 36.30 & 40.99 & 44.67 & 41.36 & 43.02 & -47.03 \\
\hline
\end{tabular}

With an increase in the shading degree, the GY indices gradually decreased, while the 1000-grain weight of the L40 and L20 treatments increased. Compared with the L60 treatment, the decrease in the kernel number per spike was primarily caused by the amount of decrease of the small grains for the L40 and L20 treatments. The yield of the L80 treatment decreased significantly compared with the CK, which is different from the results reported by $\mathrm{Mu}$ et al. (2009). This difference may be due to sufficient irrigation in this experiment since there was a larger GY for the CK treatment (Mu et al., 2010). The yield gradually increased with a decrease in the shading degree (Fig. 7a), and the yield change rate was different in each treatment.

Shading significantly reduced the GY of L80 treatment compare to CK treatment, but the WUE was not obvious, and there was little difference. The reduction in water consumption weakened the reduction in GY. The increase in HI also promoted the increase in WUE of L80 treatment. The increase in the harvest index of the L80 treatment indicated that the shading could promote the conversion of photosynthates to yield (Zhang et al., 2016). The ET decreased significantly, but the decrease in the WUE was not significant when the shading degree increased. According to $\mathrm{Xu}$ et al. (2016), when the shading degree was $12 \%$, the yield increased, indicating that a higher WUE could be achieved under slight shading. In the areas with water shortages and greater light intensities, the crop yield will decrease under inadequate irrigation, and the WUE will be further increased under shading. In terms of the comprehensive yield, ET and WUE, the shading degree should be between 0 and 0.2 .

The existing research on the effect of light on crops, crop yield, or the water consumption of fruit trees is based on a certain shading degree of the local natural solar radiation. The target SRI is not quantitative. With quantitative SRI, excessive radiation can be shaded, and rainy-day radiation will be increased to obtain a high yield of grain. However, crop species, growing stages, and geographical locations differ. The saturated light intensity in the different growing stages can be used as a reference for quantitative analysis.

\section{Conclusions}

The shading delayed the growth period of the wheat, and $80 \%$ of the full radiation increased the transformation of the photosynthates to the yield of grain. With the increase in the shading degree, the ET of the wheat gradually decreased. The ET was concentrated from the jointing to the filling stages. The daily ET was greater from the 
booting to the filling stages with the peak time from 12:00 to 14:00. When the solar radiation was less than $80 \%$, the GY decreased significantly with a similar WUE. To ensure a consistent yield of grain and improve the effect of shading on WUE, shading time and degree should be reduced. Shading time should be from the booting stage to the filling stage, and shading degrees should not more than $20 \%$ of natural solar radiation.

Acknowledgments. The project was supported by the National Natural Science Foundation of China (No. 51609197), CAS "Light of West China" Program (No. XAB2016AW06), Programme of Introducing Talents of Discipline to Universities (No. 104-451115012), and Scientific Research Program Funded by Shaanxi Provincial Education Department (No. 16JS084).

\section{REFERENCES}

[1] Ashraf, M., Harris, P. J. C. (2013): Photosynthesis under stressful environments: an overview. - Photosynthetica 51(2): 163-190.

[2] Bogo, A., Trezzi, C., Rufato, L. (2012): The effect of hail protection nets on Glomerella leaf spot in 'royal Gala' apple. - Crop Protection 31(1): 40-44.

[3] Dandan, Z., Jiayin, S., Kun, L., Quanru, L., Quanqi, L. (2013): Effects of irrigation and wide-precision planting on water use, radiation interception, and grain yield of winter wheat in the North China Plain. - Agricultural Water Management 118: 87-92.

[4] Girona, J., Behboudian, M. H., Mata, M., Del Campo, J., Marsal, J. (2012): Effect of hail nets on the microclimate, irrigation requirements, tree growth, and fruit yield of peach orchards in Catalonia (Spain). - Journal of Horticultural Science and Biotechnology 87(6): 545-550.

[5] Gommers, C. M. M., Visser, E. J. W., St Onge, K. R., Voesenek, L. A. C. J., Pierik, R. (2013): Shade tolerance: when growing tall is not an option. - Trends in Plant Science 18(2): 65-71.

[6] Guidi, L., Lo Piccolo, E., Landi, M. (2019): Chlorophyll fluorescence, photoinhibition and abiotic stress: does it make any difference the fact to be a $\mathrm{C} 3$ or $\mathrm{C} 4$ species? Frontiers in Plant Science 10(February): 1-11.

[7] Haywood, J. M., Bellouin, N., Jones, A., Boucher, O., Wild, M., Shine, K. P. (2011): The roles of aerosol, water vapor and cloud in future global dimming/brightening. - Journal of Geophysical Research: Atmospheres 116(D20).

[8] Ili, S. Z., Milenkovi, L., Dimitrijevi, A., Stanojevi, L., Cvetkovi, D., Kevre, Ž., Fallik, E., Mastilovi, J. (2017): Light modification by color nets improve quality of lettuce from summer production. - Scientia Horticulturae 226: 389-397.

[9] Kalyanasundaram, K., Graetzel, M. (2010): Artificial photosynthesis: biomimetic approaches to solar energy conversion and storage. - Current Opinion in Biotechnology 21(3): 298-310.

[10] Li, H., Jiang, D., Wollenweber, B., Dai, T., Cao, W. (2010): Effects of shading on morphology, physiology and grain yield of winter wheat. - European Journal of Agronomy 33(4): 267-275.

[11] Lopez, G., Boini, A., Manfrini, L., Torres-ruiz, J. M., Pierpaoli, E., Zibordi, M., Losciale, P. (2018): Effect of shading and water stress on light interception, physiology and yield of apple trees. - Agricultural Water Management 210(August): 140-148.

[12] McCaskill, M. R., McClymont, L., Goodwin, I., Green, S., Partington, D. L. (2016): How hail netting reduces apple fruit surface temperature: a microclimate and modelling study. - Agricultural and Forest Meteorology 226: 148-160. 
[13] Miralles, J., Martínez-Sánchez, J. J., Franco, J. A., Bañón, S. (2011): Rhamnus alaternus growth under four simulated shade environments: morphological, anatomical and physiological responses. - Scientia Horticulturae 127(4): 562-570.

[14] Mo, Z., Li, W., Pan, S., Fitzgerald, T. L., Xiao, F., Tang, Y., Wang, Y., Duan, M., Tian, H., Tang, X. (2015): Shading during the grain filling period increases 2-acetyl-1pyrroline content in fragrant rice. - Rice 8(1): 9.

[15] Mu, H. R., Jiang, D., Dai, T. B., Zhang, C. H., Jing, Q., Cao, W. X. (2009): Effects of shading on wheat grain starch quality and redistribution of pre-anthesis stored nonstructural carbohydrates. - Ying Yong Sheng Tai Xue Bao $=$ The Journal of Applied Ecology 20(4): 805-810.

[16] Mu, H., Jiang, D., Wollenweber, B., Dai, T., Jing, Q., Cao, W. (2010): Long-term Low Radiation Decreases Leaf Photosynthesis, Photochemical Efficiency and Grain Yield in Winter Wheat. - Journal of Agronomy and Crop Science 196(1): 38-47.

[17] Mupambi, G., Anthony, B. M., Layne, D. R., Musacchi, S., Serra, S., Schmidt, T., Kalcsits, L. A. (2018): The influence of protective netting on tree physiology and fruit quality of apple: a review. - Scientia Horticulturae 236: 60-72.

[18] NBS (2014): China Statistical Yearbook [Online]. - National Bureau of Statistics of China, Beijing.

[19] Sonoike, K. (2011): Photoinhibition of photosystem I. - Physiologia Plantarum 142(1): 56-64.

[20] Sorrentino, G., Cerio, L., Alvino, A. (1997): Effect of shading and air temperature on leaf photosynthesis, fluorescence and growth in lily plants. - Scientia Horticulturae 69(3-4): 259-273.

[21] Tikkanen, M., Mekala, N. R., Aro, E. M. (2014): Photosystem II photoinhibition-repair cycle protects Photosystem i from irreversible damage. - Biochimica et Biophysica Acta - Bioenergetics 1837(1): 210-215.

[22] Xie, Y., Zhang, H., Zhu, Y., Zhao, L., Yang, J., Cha, F., Liu, C., Wang, C., Guo, T. (2017): Grain yield and water use of winter wheat as affected by water and sulfur supply in the North China Plain. - Journal of Integrative Agriculture 16(3): 614-625.

[23] Xu, C., Tao, H., Wang, P., Wang, Z. (2016): Slight shading after anthesis increases photosynthetic productivity and grain yield of winter wheat (Triticum aestivum L.) due to the delaying of leaf senescence. - Journal of Integrative Agriculture 15(1): 63-75.

[24] Yu, G., Wang, Q. (2010): Ecophysiology of Plant Photosynthesis, Transpiration, and Water Use. - Science Press, Beijing.

[25] Zhang, Y., Shen, Y., Sun, H., Gates, J. B. (2011): Evapotranspiration and its partitioning in an irrigated winter wheat field: a combined isotopic and micrometeorologic approach. - Journal of Hydrology 408(3-4): 203-211.

[26] Zhang, Y. S., Feng, W., Zhang, H. Y., Qi, S. L., Heng, Y. R., Guo, B. B., Li, X., Wang, Y. H., Guo, T. C. (2016): Effects of shading and nitrogen rate on photosynthetic characteristics of flag leaves and yield of winter wheat. - Chinese Journal of EcoAgriculture 9: 1177-1184.

[27] Zheng, C., Yu, Z., Yu, S. H. I., Cui, S., Dong, W., Zhang, Y., Zhao, J. (2014): Effects of tillage practices on water consumption, water use efficiency and grain yield in wheat field. - Journal of Integrative Agriculture 13(11): 2378-2388.

[28] Zhou, L. L., Liao, S. H., Wang, Z. M., Wang, P., Zhang, Y. H., Yan, H. J., Gao, Z., Shen, S., Liang, X. G., Wang, J. H., Zhou, S. L. (2018): A simulation of winter wheat crop responses to irrigation management using CERES-Wheat model in the North China Plain. - Journal of Integrative Agriculture 17(5): 1181-1193. 